\title{
META-ANALYSIS THE EFFECT OF POST ISOMETRIC RELAXATION ON UPPER TRAPEZIUS MYOFASCIAL PAIN SYNDROME
}

\author{
Alfiya Zulfa Indana'), Setyo Sri Rahardjo²), Hanung Prasetya3) \\ 1)Masters Program in Public Health, Universitas Sebelas Maret \\ 2) Faculty of Medicine, Universitas Sebelas Maret \\ 3)Study Program of Acupuntur, Health Polytechnics, Ministry of Health Surakarta
}

\begin{abstract}
Background: Myofascial pain syndrome (MPS) is a common clinical problem, arising from the muscle and produces sensory, motoric, and autonomic symptoms. They are caused by myofascial trigger points which are focal areas of tenderness caused by hypercontracted muscle tissue. Post-isometric relaxation is a manual therapy technique suggested in the treatment of myofascial trigger points. The purpose of this study was to examine the effect of post isometric relaxation on upper trapezius myofascial pain syndrome.
\end{abstract}

Subjects and Method: A systematic review and meta analysis was conducted by collecting articles from PubMed, Science Direct, Google Schoolar, and PEDro databases. The determination of selected articles based on eligible criteria using PICO: (1) Population= individu aged 18-65 years, (2) Intervention= post isometric relaxation, (3) Comparison $=$ other therapy, and (4) Outcome $=$ upper trapezius myofascial pain syndrome. Keywords used ("MPS Upper Trapezius" OR "Myofascial pain syndrome upper trapezius") AND ("PIR" OR "Post isometric relaxation) AND "randomized contrplled trial". The inclusion criteria were full text, randomized controlled trial study, published from 2010 to 2020, and reported Mean and SD. The articles were collected by PRISMA flow diagram. The selected articles were quantitatively examined by Review Manager 5.3.

Results: A meta-analysis involved 9 studies showed that post isometric relaxation reduced upper trapezius myofascial pain syndrome, but it was statistically nonsignificant $(\mathrm{SMD}=0.18 ; 95 \% \mathrm{CI}=-0.36$ to $0.72 ; \mathrm{p}=0.510)$.

Conclusion: Post isometric relaxation reduces upper trapezius myofascial pain syndrome, but it is statistically non-significant.

Keywords: post isometric relaxation, laser therapy, upper trapezius myofascial pain syndrome

\section{Correspondence:}

Alifiya Zulfa Indana. Masters Program in Public Health, Universitas Sebelas Maret. Jl. Ir. Sutami 36A, Surakarta 57126, Central Java. Email: alifiyaindanao@gmail.com. Mobile: 082240463478. 